\title{
Evaluating barley feed fractions from integrated ethanol-starch production in diets of ruminants
}

\author{
MATTI NÄSI \\ University of Helsinki, Department of Animal Husbandry, \\ SF-00710 Helsinki, Finland
}

\begin{abstract}
A new process for the integrated production of ethanol and starch yields barley fractions with different types and contents of carbohydrates and protein. The barley hulls and bran consist mainly of lignocellulose, the barley molasses has considerable contents of sugars and soluble protein, the barley protein contains $40 \%$ protein and has a low fibre level, while the barley fibre consists mainly of cereal cell walls and its NDF is high. The amino acid content of the barley fractions is almost the same as in the barley raw material. The nutritive value of the barley fractions was assessed in six digestibility trials performed with rams. Barley protein and barley molasses had high digestibilities, 90-95 \% for OM and 87-93\% for CP; barley fibre had slightly lower digestibilities, $73 \%$ for OM and 77 for CP, while barley hulls and bran had low values, $58 \%$ for OM and $64 \%$ for CP. The nitrogen balance improved with increasing level of the barley fractions in hay diet. The FU values were 1.15, 0.94, 0.97, $0.73,0.30$ and 0.93 per $\mathrm{kg}$ DM for barley protein, fibre, molasses, hulls + bran, hulls and a mixture of fibre and molasses, respectively. The present experiments indicated that, apart from the product of the dehulling process, the barley fractions obtained are of high nutritive value.
\end{abstract}

Index words: barley, starch-ethanol production, barley feed fractions, digestibility, ruminant

\section{Introduction}

Conventional distillers' feeds are products resulting from the yeast fermentation of whole cereal grains. An alternative approach, attractive for large plants, is initial wet milling of the grain, followed by separating out of starch, protein and fibre, to obtain various feed products. In Finland, a new technique of integrated alcohol-starch production from barley, developed by Alko Ltd, is replacing the former traditional alcohol production method. In fact, starch and ethanol production from grains are in many respects very similar processes. Both utilize the starch and leave the other components of the raw material to be recovered as by-products for animal feed purposes. Also, most cereals contain a 
B-starch fraction, which is difficult to recover but can easily be utilized in ethanol production. By integrating the starch and ethanol production, many process steps can be combined and many unit operations shared. Investment cost can be cut considerably by using the same machines for two processes (LehmussaARI 1987). The by-products also contribute significantly to the economic viability of the production plant. The greater amount of by-products produced from barley feedstock compared with wheat or maize adds to the interest of the new technique. About $60 \%$ of barley protein can be recovered as a separate fraction and the value of the byproducts to be used in animal feeding is a question of economic importance. Barley distillers' feeds from the traditional ethanol process have been found to have a relatively low nutritive value, due to their denatured protein and high fibre content (Näsı 1984).

Since no industrial-scale process for integrated starch-ethanol production based on barley grain until has yet been described, research is lacking on the feeding value and utilization of the barley feed fractions in animal nutrition. The purpose of this report is to offer information on the nutritional value of the barley by-products for ruminants.

\section{Description of the alcohol-starch production process}

Precleaned barley is coarsely milled with a hammer to break up the kernels and expose the starch molecules. Coarse fibre, consisting mostly of hulls and brans, is removed by aspiration and sieving, which greatly reduces the fibre content in wet-milling. Up to $10 \%$ of the barley weight can be removed by this method without great losses of starch. The barley hulls and brans can be further fractionated into two kinds of products, differing in their lignocellulose content.

The coarse flour from the dry milling is soaked with process water to soften the cell structures and facilitate liberation of the starch. The process is promoted by endogenous grain enzymes, and enzymes such as cellulases, hemicellulases and $\beta$-glucanase can also be added, since this enables better separation of the constituents into pure fractions in later stages of the process. During soaking, soluble material is extracted from the barley into the water and separated from the solids by centrifugation. The supernatant containing solubles is evaporated to a syrup like product called barley molasses, which also contains soluble proteins from the grain. As barley molasses contains up to $40 \%$ fermentable sugars, it can also be utilized in alcohol fermentation. In this case the nonfermentables of barley molasses remain in the thin stillage.

In the next process stage, the fibre material of the cell walls is removed by sieving. Protein, starch and solubles pass through the screen. Oversized fibre material is separated, dehydrated mechanically with a screw-press and dried to a separate feed component called barley fibre. The barley molasses or evaporated thin stillage can be combined with this fraction.

The sieved slurry, containing A and B starch, protein and soluble impurities, is split into three fractions with the help of separators and multistage hydrocyclones. Up to $75 \%$ of total starch is recovered as pure $A$ starch. This is separated mechanically from the barley protein and the water is removed from both fractions by decanting. The protein fraction is dried separately to a feed ingredient called barley protein. The dehydration of the barley protein and barley fibre is carried out at a relatively low temperature by a fluid-bed process.

Dewatered B starch is utilized in alcohol production, comprising the normal operations of mashing, fermentation and distillation. As most of the feed fractions have already been removed in the starch production, the amount of nonfermentables is very small compared with that in the conventional alcohol process. The stillage is clarified with a separator and the solubles recycled in the process. 
INTEGRATED ETHANOL - STARCH PRODUCTION

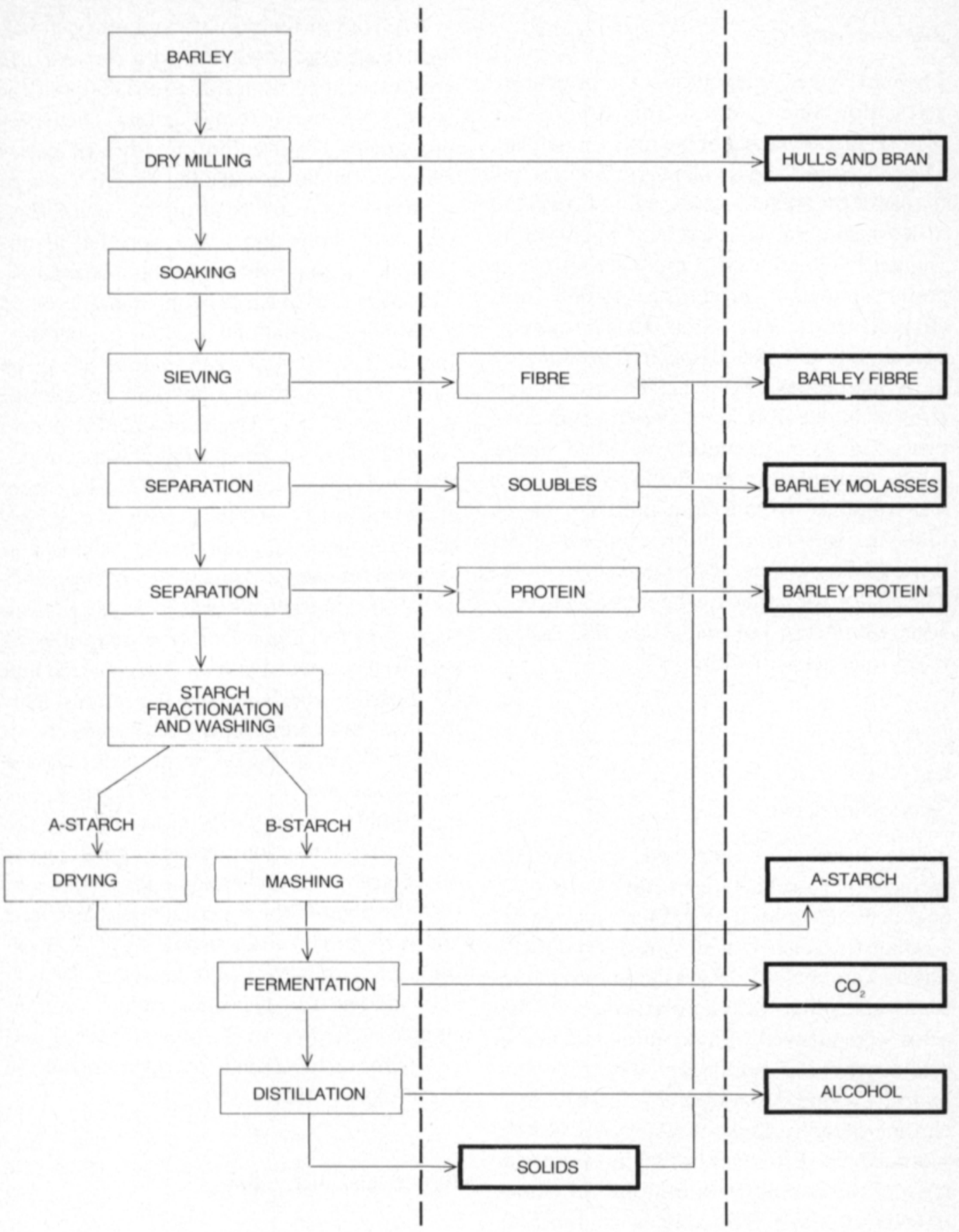

Figure 1.

It is technically possible to separate the barley feed fractions completely or combine them within certain limits. Figure 1. shows the general flow diagram of the starch-ethanol production process and the potential stages at which the feed fractions are recovered. 


\section{Materials and methods}

\section{Test materials}

The barley feed fractions for the present investigation were obtained from Alko Ltd, a pilot-scale starch ethanol factory in Rajamäki. The process at the pilot plant corresponds well to that of the ethanol-starch plant of Alko Ltd in Koskenkorva, which started operation in August 1987 and utilises 150000 tons barley grain annually, producing 15000 tons ethanol, 30000 tons starch, 10000 tons carbon dioxide and 65000 tons feed products on a dry matter basis per year. The barley protein and barley fibre in the present study were processed from previously dehulled barley (10\% extraction rate). The hulls and brans were obtained from a flour mill. The barley molasses was obtained by evaporation of process water to a dry matter content of $45 \%$. The mixture of barley fibre and molasses consisted of one third of evaporated thin stillage dried together with fibre.

\section{Analysis of feeds}

The feeds were analysed by standard methods. Neutral detergent fibre (NDF) and acid detergent fibre (ADF) were assayed according to GoERING and VAN SOEST (1970). Sugars were analysed by gas liquid chromatography and starch with a polarimeter. Amino acids were assayed with an automatic amino acid analyser (Chromacon 400) following hydrolysis and separation by ion-exchange chromatography, and available lysine was determined by difference following pre-treatment of the samples with fluoronitrobenzene (PAO et al. 1963). The mineral composition was measured with a Varian Techtron AA1000 atomabsorption spectrophotometer. Phosphorus was determined by the method of TAYSSKY and SHORR (1953), sodium and potassium concentrations were measured by flame photometry (Corning 435).

\section{Feed evaluation}

Six series of digestibility and nitrogen balance trials were conducted with four rams in each experiment to test the feed value of the six different barley feed fractions. The barley protein, barley fibre and mixture of barley fibre and molasses were fed at two levels of inclusion, 33 or $67 \%$ of the hay based diet, the barley hulls and brans were fed at one level, $67 \%$, and the barley molasses at $50 \%$. The ration was given at maintenance level, 55 $\mathrm{g}$ DM per kg metabolic body weight per day. In addition, $50 \mathrm{~g}$ mineral mixture was given daily. The Finnsheep rams had an average weight of $37 \mathrm{~kg}$. The experimental period lasted 21 days, of which 14 days were considered to be an adaptation period. The faeces and urine production in each seven-day period were collected quantitatively, weighed and sampled for chemical analyses. The digestibility of the ingredients was calculated by a regression technique from the quantities of each feed consumed in each digestion trial and the digestion coefficients of the rations. This method eliminates the associative effects on digestibility of giving different feeds together (Schneider and Flatt 1976). However, the digestibility of the barley molasses, and the hull and bran fractions were computed by the difference method. The same lot of hay was used throughout the experiment as basic feed and it contained crude protein 9.9, ether extract 2.5 , crude fibre 34.4 and ash $6.4 \%$ on a dry matter basis. Net energy values were calculated according to SALO et al. (1982) and values for metabolizable energy according to MAFF (ANON. 1975).

\section{Results and discussion}

\section{Composition of the barley fractions}

The chemical composition of the barley feed fractions obtained from the integrated starch-ethanol process is presented in Table 1. The proximate composition of the fractions primarily deviated from that of the barley 
Table 1. Chemical composition of various fractions of integrated ethanol-starch production using barley.

\begin{tabular}{|c|c|c|c|c|c|c|c|}
\hline & $\begin{array}{l}\text { Barley } \\
\text { protein }\end{array}$ & $\begin{array}{l}\text { Barley } \\
\text { fibre }\end{array}$ & $\begin{array}{c}\text { Barley } \\
\text { hulls + } \\
\text { bran }\end{array}$ & $\begin{array}{c}\text { Barley } \\
\text { hulls }\end{array}$ & $\begin{array}{l}\text { Barley } \\
\text { solubl. }\end{array}$ & $\begin{array}{c}\text { Barley } \\
\text { fibre + } \\
\text { solubl. }\end{array}$ & $\begin{array}{l}\text { Hulled } \\
\text { barley }\end{array}$ \\
\hline \multicolumn{8}{|l|}{ Composition, $\%$ in Dm } \\
\hline Dry matter & 94.3 & 95.5 & 88.9 & 90.0 & 42.8 & 94.0 & 87.2 \\
\hline Ash & 4.2 & 3.9 & 5.3 & 4.5 & 12.2 & 6.4 & 2.4 \\
\hline Crude protein & 37.6 & 17.2 & 11.2 & 4.7 & 24.7 & 19.2 & 11.5 \\
\hline Ether extract & 6.2 & 2.2 & 3.7 & 1.5 & 1.6 & 5.5 & 2.3 \\
\hline Crude fibre & 2.9 & 11.2 & 21.3 & 29.3 & - & 13.6 & 3.3 \\
\hline NFE & 49.1 & 65.6 & 58.5 & 52.2 & 61.5 & 55.3 & 80.6 \\
\hline Starch & 32.1 & 9.2 & 15.7 & 11.9 & 2.3 & 10.5 & \\
\hline Total sugars & 8.5 & 8.8 & 12.1 & 8.1 & 55.7 & 9.1 & \\
\hline Neutral deterg. fibre & 3.0 & 48.4 & 53.5 & 68.1 & - & 42.9 & 20.4 \\
\hline Acid detergent fibre & 3.0 & 12.6 & 26.3 & 34.8 & - & 18.6 & 4.1 \\
\hline Acid detergent lignin & 0.6 & 2.9 & 3.9 & 2.5 & - & 3.2 & 1.0 \\
\hline \multicolumn{8}{|l|}{ Amino acids. $\mathrm{g} / 16 \mathrm{~g} \mathrm{~N}$} \\
\hline Alanine & 3.9 & 7.3 & 4.3 & 3.6 & 6.0 & 4.3 & 4.0 \\
\hline Arginine & 4.0 & 4.4 & 5.0 & 4.5 & 2.8 & 4.0 & 5.4 \\
\hline Aspartic acid & 5.0 & 5.6 & 6.2 & 5.9 & 6.2 & 5.3 & 5.5 \\
\hline Cystine & 2.2 & 2.7 & 2.2 & 2.2 & 2.8 & 2.0 & 2.2 \\
\hline Glutamic acid & 21.3 & 15.8 & 19.4 & 18.7 & 15.4 & 17.5 & 20.0 \\
\hline Glycine & 3.7 & 5.4 & 4.3 & 3.6 & 5.4 & 4.0 & 3.5 \\
\hline Histidine & 2.2 & 2.1 & 2.2 & 2.0 & 2.4 & 1.9 & 2.1 \\
\hline Isoleucine & 2.4 & 2.8 & 3.3 & 3.1 & 3.2 & 3.2 & 3.2 \\
\hline Leucine & 7.1 & 5.9 & 6.4 & 6.0 & 6.5 & 5.8 & 6.5 \\
\hline Lysine & 3.2 & 3.4 & 3.8 & 3.4 & 4.6 & 2.6 & 3.3 \\
\hline Methionine & 1.8 & 1.6 & 1.8 & 1.8 & 2.0 & 1.5 & 1.6 \\
\hline Phenylalanine & 5.8 & 3.8 & 4.2 & 4.3 & 3.6 & 4.2 & 4.9 \\
\hline Proline & 12.2 & 8.0 & 7.6 & 9.0 & 6.3 & 8.5 & 9.6 \\
\hline Serine & 4.3 & 3.8 & 4.2 & 3.8 & 4.3 & 3.8 & 4.1 \\
\hline Threonine & 3.4 & 4.5 & 3.4 & 3.2 & 4.3 & 3.2 & 3.3 \\
\hline Tyrosine & 4.7 & 4.4 & 4.3 & 4.4 & 5.3 & 2.9 & 2.8 \\
\hline Valine & 4.7 & 4.4 & 4.3 & 4.4 & 5.3 & 4.5 & 4.6 \\
\hline Available lysine & 3.1 & 3.4 & 3.2 & - & 4.3 & 2.3 & 3.2 \\
\hline \multicolumn{8}{|l|}{ Mineral composition } \\
\hline Ca g/kg DM & 2.37 & 1.39 & 1.38 & 1.70 & 1.06 & 1.84 & 0.97 \\
\hline $\mathrm{Pg} / \mathrm{kg} \mathrm{DM}$ & 7.89 & 6.04 & 15.06 & 6.42 & 9.54 & 8.73 & 4.40 \\
\hline $\mathrm{Mg} \mathrm{g} / \mathrm{kg} \mathrm{DM}$ & 2.61 & 2.68 & 1.43 & 0.74 & 5.36 & 3.54 & 1.53 \\
\hline $\mathrm{K} \mathrm{g} / \mathrm{kg} \mathrm{DM}$ & 9.79 & 11.43 & 10.02 & 5.80 & 17.67 & 13.73 & 6.08 \\
\hline $\mathrm{Na} \mathrm{g} / \mathrm{kg} \mathrm{DM}$ & 1.15 & 0.61 & 0.59 & - & 5.09 & 4.49 & 0.60 \\
\hline $\mathrm{Fe} \mathrm{mg} / \mathrm{kg} \mathrm{DM}$ & 139 & 53 & 429 & 133 & 31 & 130 & 85 \\
\hline Cu mg/kg DM & 15 & 13 & - & - & 6 & 13 & 12 \\
\hline $\mathrm{Zn} \mathrm{mg} / \mathrm{kg} \mathrm{DM}$ & 61 & 54 & 31 & 13 & 31 & 46 & 37 \\
\hline $\mathrm{Mn} \mathrm{mg/kg} \mathrm{DM}$ & 61 & 21 & 46 & 23 & 35 & 31 & 45 \\
\hline
\end{tabular}

grain in the contents of protein and fibre. Most of the starch has been removed in the process and the proportion of the other constituents of barley are two to four times as great as in the original material. The barley protein is the reserve protein fraction of the endosperm obtained in the starch-washing step, usually containing $40-50 \%$ protein and
$15-20 \%$ starch, according to the process surveillance data (ANON. 1987). In the present sample, $38 \%$ crude protein and up to $32 \%$ of starch was found. The high starch content in this sample may be caused by inadequate addition of enzyme in the soaking process, which leads to incomplete separation of the components into pure fractions. The fat 
content is $\mathbf{2}-\mathbf{3}$ times as high as in the original barley grain. The crude fibre content is minimal. Maize and wheat gluten contain more protein, 70-84 \% (SALo et al. 1982), than the product derived from barley. Barley contains variable amounts of highly viscous material like $\beta$-glucans (Åman 1986) and it also has small-granule-size B starch, which is difficult to extract, and these factors lower the protein content.

Barley fibre is obtained by sieving the grain slurry and it contains mainly cereal cell walls, its NDF amounting to $48 \%$, but very little lignified fibre remains in this fraction. The protein and fat contents of barley fibre are a little higher than in the raw material. As a feed ingredient, barley fibre corresponds to corn gluten feed from the wet milling starch process, having a similar composition (STAPLES et al. 1984, Hsu et al. 1987). Barley molasses contains soluble grain constituents, a considerable amount of sugars $(56 \%)$ and $25 \%$ protein. Barley hulls consist mainly of lignocellulose and the proportion of ADF is $35 \%$, which agrees with the data given by Salo and Kotilainen (1970), Bach KNUdSEN (1982) and Hsu et al. (1987).

The amino acid content of the barley fractions is almost the same as in the barley raw material. Barley molasses has a higher lysine content than the other fractions. Cereal albumin is water-soluble and its lysine content is higher than that of the other proteins in barley (Briggs 1978). The available lysine is almost the same as the total lysine, which indicates that it was not damaged by the process, and that its quality remained good. Näsı (1984, $1985)$ reported earlier that the content of available lysine in barley distillery products was reduced. Barley molasses had fairly high contents of sodium and potassium compared with the other fractions, which is partly caused by the process additions (Table 1).

\section{Feed value of the barley fractions}

All the test feeds were accepted readily by the sheep and feed refusals were very infre- quent in all the treatments. Table 2 presents the digestibility values of the nutrients in the diets containing the various barley fractions at two or one level of the ration. The average digestibility obtained by regression for the test hay was $59.9 \%$ for organic matter, $57.4 \%$ for crude protein, $32.5 \%$ for ether extract, $63.7 \%$ for crude fibre and $58.9 \%$ for nitrogen free extracts, the variation among the different experiments being very small. The nitrogen balance increased with increasing level of the barley fractions in the rations. A negative $\mathrm{N}$ balance was found in the diet containing barley hulls, which had a low protein content.

Table 3 . gives the digestibility coefficients for the different barley feed products and their calculated feed values. Barley protein and barley molasses were both very highly digestible, 90-95 \% for organic matter and 87$93 \%$ for crude protein. Barley fibre was digested a little less well (73\% for OM and $77 \%$ for CP) than barley meal, having the same level as many milling by-products (SALO et al. 1982). In sheep, Hsu et al. (1987) report over $70 \%$ digestibilities for OM, NDF and ADF in corn fibre, and in cows wet corn gluten feed has had digestibilities of $67 \%$ for OM, $80 \%$ for CP, $63 \%$ for NDF and $42 \%$ for ADF (StAPLes et al. 1984). NDF in corn gluten feed has been described as highly and rapidly digested in ruminants (GREEN et al. 1987), but FIRKINS et al. (1985) indicated that dried corn gluten feed cellulose was less readily degraded in the rumen. Reduced digestibilities were also observed when dried and ensiled maize gluten feed were compared in a trial with wethers, $75.0 \%$ vs. $81.9 \%$ for OM and 65.5 vs. $71.5 \%$ for $\mathrm{CP}$, respectively (Visser and TAmminga 1987). A possible explanation for this may be that the drying changes the structure of gluten feed cellulose from amorphous to more rigid and crystalline. In wet gluten feed, the cellulose is swollen, which increases its susceptibility to microbial attack. The particle size of the barley fibre is very small, due to the requirements of the process and particle phase dilution rate is 
Table 2. Digestibility coefficients of the nutrients of diets containing different barley feed fractions and nitrogen balance data.

\begin{tabular}{|c|c|c|c|c|c|c|}
\hline \multirow{2}{*}{$\begin{array}{l}\text { Ingredient } \\
\text { Level in diet }\end{array}$} & \multicolumn{2}{|c|}{ Barley protein } & \multicolumn{2}{|c|}{ Barley fibre } & \multicolumn{2}{|c|}{$\begin{array}{c}\text { Barley fibre } \\
+ \text { molasses }\end{array}$} \\
\hline & $33 \%$ & $67 \%$ & $33 \%$ & $67 \%$ & $33 \%$ & $67 \%$ \\
\hline Organic matter & 71.6 & 80.6 & 65.3 & 69.0 & 62.7 & 66.4 \\
\hline Crude protein & 78.7 & 84.4 & 69.1 & 73.4 & 63.3 & 71.6 \\
\hline Ether extract & 50.3 & 62.9 & 63.8 & 70.5 & 52.3 & 65.8 \\
\hline Crude fibre & 64.2 & 69.7 & 61.4 & 53.9 & 60.6 & 51.8 \\
\hline NFE & 73.9 & 83.1 & 66.4 & 68.1 & 64.5 & 70.7 \\
\hline \multirow[t]{2}{*}{$\mathrm{N}$-balance, g/d } & 4.3 & 7.5 & 3.3 & 5.0 & 1.7 & 4.3 \\
\hline & \multicolumn{2}{|c|}{$\begin{array}{l}\text { Barley hulls } \\
+ \text { bran }\end{array}$} & \multicolumn{2}{|c|}{ Barley hulls } & \multicolumn{2}{|c|}{ Barley molasses } \\
\hline Level in diet & \multicolumn{2}{|c|}{$67 \%$} & \multicolumn{2}{|c|}{$67 \%$} & \multicolumn{2}{|c|}{$50 \%$} \\
\hline Organic matter & \multicolumn{2}{|c|}{59.1} & \multicolumn{2}{|c|}{49.0} & \multicolumn{2}{|c|}{82.3} \\
\hline Crude protein & \multirow{2}{*}{\multicolumn{2}{|c|}{$\begin{array}{l}64.1 \\
58.4\end{array}$}} & \multirow{2}{*}{\multicolumn{2}{|c|}{22.5}} & \multirow{2}{*}{\multicolumn{2}{|c|}{$\begin{array}{l}85.3 \\
53.7\end{array}$}} \\
\hline Ether extract & & & & & & \\
\hline Crude fibre & \multicolumn{2}{|c|}{43.4} & \multicolumn{2}{|c|}{43.7} & \multicolumn{2}{|c|}{59.0} \\
\hline NFE & \multicolumn{2}{|c|}{65.1} & \multicolumn{2}{|c|}{54.8} & \multicolumn{2}{|c|}{87.0} \\
\hline N-balance, g/d & \multicolumn{2}{|c|}{1.0} & \multicolumn{2}{|c|}{-2.0} & \multicolumn{2}{|c|}{13.8} \\
\hline
\end{tabular}

Table 3. Nutrient digestibilities and calculated feed values of various fractions of integrated ethanol-starch production from barley.

\begin{tabular}{lcccccc}
\hline Barley traction & Protein & Fibre & $\begin{array}{c}\text { Hulls } \\
\text { bran }\end{array}$ & Hulls & Molasses & $\begin{array}{c}\text { Fibre + } \\
\text { molasses }\end{array}$ \\
\hline $\begin{array}{l}\text { Digestibility, \% } \\
\text { Organic matter }\end{array}$ & 90.0 & 72.6 & 58.0 & 54.3 & 95.2 & 71.3 \\
Crude protein & 87.3 & 76.5 & 64.2 & -2.7 & 92.6 & 77.8 \\
Ether extract & 72.1 & 76.9 & 59.0 & 42.3 & 77.5 & 73.6 \\
Crude fibre & 99.9 & 35.6 & 30.6 & 37.6 & - & 35.6 \\
NFE & 93.1 & 77.9 & 66.7 & 52.8 & 98.0 & 77.5 \\
Feed values & & & & & & \\
FU/kg DM & 1.15 & 0.94 & 0.73 & 0.30 & 0.97 & 0.93 \\
$\mathrm{~kg} /$ FU & 0.92 & 1.13 & 1.53 & 3.67 & 2.41 & 1.15 \\
DCP, \% in DM & 32.8 & 13.1 & 7.2 & 0 & 22.9 & 14.9 \\
DCP, g/FU & 286 & 140 & 98 & 0 & 236 & 161 \\
ME, MJ/kg DM (MAFF) & 14.16 & 11.20 & 8.88 & 6.01 & 13.48 & 11.08 \\
NE, MJ/kg DM (NEL) & 8.58 & 6.32 & 4.81 & 3.09 & 8.14 & 6.35 \\
\hline
\end{tabular}

probably high, thus decreasing rumen digestion. These factors can lower the digestion level of barley fibre, which could be expected to be higher in view of its chemical composition. The barley hulls and bran, especially the former had low digestibility, of the same magnitude as straw. Nearly all the lignin of the kernel is assigned to the hulls (SALAMONSSON et al. 1980, BACH KNUdSEN 1982), which makes the cell wall very rigid, and difficult to digest.

The energy values of barley protein and molasses were high, $0.97-1.15 \mathrm{FU} / \mathrm{kg} \mathrm{DM}$, and the ME values were $13.5-14.2 \mathrm{MJ} / \mathrm{kg}$ DM. In these feed fractions the digestible protein content was also high. Barley fibre had 
intermediate energy and protein values. Barley hulls showed a low feed value, $0.30 \mathrm{FU} / \mathrm{kg}$ $\mathrm{DM}$, and the product containing barley hulls and bran was also rather poor.

The present experiments performed to assess the nutritive value of barley feed fractions indicated that these products, except those of the dehulling process, are of high nutritive value. The $\mathrm{N}$-balance results for the barley fractions are promising, but further production trials are needed to assess the protein value of the products. The traditional distillers' products contain all the nonfermenta- bles of the raw material in one fraction. Barley distillers' grain with solubles has a high content of crude fibre and the heat and other processing treatments cause the protein to react with sugars, thus decreasing its digestibility and utilization. Barley DDGS had a very low nutritive value and its protein utility was limited in ruminant feeding as well (NÄSı 1984). In the integrated production of starch and ethanol, barley by-products can be fractionated into products suitable for use in the diets of both ruminants and monogastrics.

\section{References}

ANON. 1975. MAFF (Ministry of Agriculture, Fisheries and Food) Energy allowances anf feeding systems for ruminants. Tech. Bull. 33. 79 p. London.

ANON. 1987. Alko Ltd. Quality control information.

BACH KNUdSEN, K.E. 1982. The nutrivive value of botanically defined mill fractions of barley. 1 . The protein value of husk and endosperm of Bomi and high-lysine variety M-1508. Z. Tierphysiol., Tierernähr. u. Futtemittelk. 48: 90-104.

Briggs, D.G. 1978. Barley. 612 p. Chapman \& Hall. London.

Goering, H.K. \& VAN Soest, P.J. 1970. Forage fiber analysis: apparatus, reagents, procedures and some applications. U.S. Dep. Agric. Hand b. No 379: 8-9.

Green, D.A., Stock, R.A., Goedeken, F.K. \& KlopFESTEIN, T.J. 1987. Energy value of corn wet milling by-product feeds for finishing ruminants. J. Anim. Sci. 65: 1655-1666.

Firkins, J.L., Berger, L.L. \& Fahley, G.C. 1985. Evaluation of wet distillers grains and dry corn gluten feeds for ruminants. J. Anim. Sci. 60: 847-860.

Hsu, J.T. Faulkner, D.B., Garleb, K.A. \& Barclay, R.A. 1987. Evaluation of corn fiber, cottonseed hulls, oat hulls and soybean hulls as roughage source for ruminants. J. Anim. Sci. 65: 244-255.

LehmussaAri, A. \& Ham van der, W. 1987. New process for the integrated production of barley starch and ethanol. 38 Stärke Tagung. Detmold, FDG. Mimeogr. 14 p.

NĀsı, M. 1984. Distillers dried by-products from barley as protein source for ruminants. J. Agric. Sci. Finl. 56: $213-219$.
- 1985. Distillers feeds from various grains as protein source for pigs. J. Agric. Sci. Finl. 57: 255-262.

Pao, S.R., Carter, F.L. \& Frampton, V.L. 1963. Anal. Chem. 35: 1927-1930.

SAlo, M-L. \& Kotilainen, K. 1970. On the carbohydrate composition and nutritive value of some cereals. J, Scient. Agric. Soc. Finl. 50: 21-29.

-, TUORI, M. \& KIISKInEN, T. 1982. Rehutaulukot ja ruokintanormit. 70 p. Helsinki.

Salomonsson, A-C., Theander, O. \& Westerlund, E. 1984. Chemical characterization of some Swedish cereal whole meal and bran fractions. Swed. J. Acric. Res. 14: $111-117$

SCHNEIDER, B.H. \& Flatt, P.W. 1975. The evaluation of feeds through digestibility evaluation. Univ. Georgia Press. Athens. 423 p.

Stapeles, C.R., Davis, C.L., Mccoy, G.C. \& Clark, J.H. 1984. Feeding value of wet corn gluten feed for lactating dairy cows. J. Dairy Sci. 67: 1214-1220.

TAussky, H.H. \& ShORR, E. 1953. A microcalorimetric method for the determination of inorganic phosphorus. J. Biol. Chem. 202: 675-685.

VISSER de, H. \& TAMminga, S. 1987. Influence of wet versus dry byproduct ingredients and addition of branchchain volatile fatty acids and valerate to dairy diets. 1. Feed intake, milk production and milk composition. Neth. J. Agric. Sci. 35: 163-175.

Åman, P. 1986. A note on the content of mixed-linked beta-glucans in Swedish barley. Swed. J. Agric. Res. 16: $73-75$.

Ms received 


\section{SELOSTUS}

\section{Integroidun etanoli-tärkkelystuotannon rehujakeiden arvo märehtijän ruokinnassa}

\section{Matti Näsi}

Helsingin yliopisto, Kotieläintieteen laitos, 00710 Helsinki

Alkoholin ja tärkkelyksen tuotanto aloitettiin ohrasta integroituun prosessitekniikkaan perustuvalla menetelmällă Oy Alko Ab:n Koskenkorvan tuotantolaitoksessa v. 1987. Rehu saadaan prosessista neljănă erillisenă jakeena: ohravalkuaisrehuna, ohrarehuna, ohramelassina ja tärkkelysrankkina. Jakeita voidaan yhdistäă myös seoksiksi.

Ohrarehujakeet poikkeavat kemialliselta koostumukseltaan enimmäkseen proteiini- ja kuitupitoisuuksien osalta. Ohravalkuaisrehun ja -melassin proteiinipitoisuudet ovat $25-38 \%$. Niissả kuitupitoisuus on hyvin alhainen. Ohrarehussa on runsaasti neutraalidetergenttikuitua. Ohrankuorilese ja -kuorijauho koostuvat lignifioituneesta kuidusta. Tärkkelystä jäă jonkin verran kaikkiin jakeisiin. Ohrarehujakeiden aminohappopitoisuudet ovat mel- ko lähellă raaka-aineena käytetyn ohran arvoja.

Ohravalkuaisrehun ja -melassin ravintoaineiden sulavuudet olivat korkeita (OA 90-95 \% ja RV 87-93 \%). Ohrarehun sulavuus oli văhän alempi (OA $73 \%$ ja RV $77 \%$ ). Ohrankuorilese suli huonosti (OA $58 \%$ ja RV $64 \%$ ). Păssien typpitaseet nousivat, kun heinädieetteihin lisăttiin ohrarehujakeita. Rehuyksikkőarvoiksi saatiin ohravalkuaisrehulle $1.15 / \mathrm{kg} \mathrm{ka}$, -rehulle 0.94 , -melassille 0.97 , -kuorileseelle 0.73 , -kuorijauholle 0.30 ja -rehu-melassiseokselle 0.93 , vastaavasti.

Tutkitut ohrarehujakeet kuorijakeita lukuunottamatta ovat rehuarvojen perusteella sopivia rehuraaka-aineita kotielăinten ruokinnassa käytettăvăksi. Optimaalisten käyttőmäärien ja hyvăksikäytön selvittämiseksi tarvitaan ruokintatutkimuksia tulosten varmistamiseksi. 